\title{
Traditional Phytotherapy of Vizianagaram District, Andhra Pradesh, India.
}

\author{
${ }^{1}$ S. B. Padal, ${ }^{2}$ M. Venkaiah, ${ }^{3}$ P. Chandrasekhar $\&{ }^{4}$ Y. Vijayakumar \\ ${ }^{I}$ Department of Botany, Mrs.A.V.N.Collage, Visakhapatnam-530001, Andhra Pradesh, India. \\ ${ }^{2}$ Department of Botany, Andhra University, Visakhapatnam, Andhra Pradesh, India. \\ ${ }^{3,4}$ Department of Botany, Dr.V.S. Krishna Govt. Degree College, Visakhapatnam, Andhra Pradesh, India.
}

\begin{abstract}
An ethnomedicinal survey was carried out in Vizianagaram District, and Andhra Pradesh, India. The indigenous knowledge of local traditional uses was collected through questionnaire and personal interviews during field trips. The identification and nomenclature of the listed plants were based on The Flora of Andhra Pradesh. A total of 43 plants species were identified by taxonomic description and locally by ethnomedicinal knowledge of people existing in the region. Plant specimens collected, identified, preserved and mounted were deposited in the department of botany, Andhra University, Visakhapatnam for future references.
\end{abstract}

KEY WORDS: Traditional phytotherapy, indigenous knowledge, Tribal people, Vizianagaram district, Andhra Pradesh.

\section{INTRODUCTION}

From earliest times people have made use of plants for their basic needs, sustenance, medicare and livelihood. Some plants used by tribal people are cultivated, while others grow in wild conditions. The tribals depend predominantly on plants for food, clothing, housing, medicine, oil, agricultural implements, art \& crafts and a host of other requirements. They also have some superstitious beliefs on some plants which were found to be tied/worn on the body parts to cure various ailments.

It is well known that during the process of evolution plants have synthesized compounds whose structured diversity is often beyond the dreams of even the most imaginative organic chemists. Plants are still the main source of medicines to majority of people. Reliance on traditional medicine is not only associated with the traditional belief of its effectiveness but also on harmonious existence of spirit and matter. The efficacy of herbal medicines is believed to be enhanced when they are prepared and administered by enchanting mantras and incantations.

\section{STUDY AREA}

The Vizianagaram District Kotia Hills are disputed area between the governments of Andhra Pradesh and Orissa regarding the ownership. The Kotia Hills lies between $18026^{\prime} 063^{\prime \prime}$ and $18^{\circ} 55^{\prime} 200^{\prime \prime}$ North latitudes and $83 \mathrm{o} 10^{\prime}$ ' 426" and 83o 24' 764" East longitudes, the elevation of above the mean sea level ranges from 850m to $1615 \mathrm{~m}$. The Kotia Hills surrounded on the East by Srikakulam district, on the West and South by Visakhapatnam district, on South East by Parvathipuram Revenue Division and North-West by Koraput district of Orissa state. The tribal inhabitants of the study area mainly consist of Mannedora, Konda dora Jatapu and Savara. The ethnomedicinal study was under taken with a view to find out the plants used by tribes of Kotia Hills in selected 27 pockets particularly to cure various ailments.

\section{MATERIAL AND METHODOLOGY}

Field trips to the study area were made to collect information on Traditional phytotherapy practices by the aboriginal and others through interviewing local chiefs, priests, vaidyas, herbal practitioners, elderly people and educated youths. The methodology was adopted as described by Jain (1964, 1981, 1987, and 1999), Chadwick and Marsh (1994), Hemadri (1994) and Martin (1995). Each medicinal practice was cross checked with 3 or 4 informants. Ethnoveterinary data and the vernacular names were collected for documentation. Plants specimens were collected and identified by referring to standard Flora, viz. Hooker (1872-1897), Gamble and Fischer (1915), Pullaiah (1997) and few other local floras.

\section{ENUMERATION}

Enumeration of Plants In the following list, botanical name is followed by name of the family the name given telugu, description of the plant, flowering and fruiting in Vizianagaram District, Andhra Pradesh, India. The detailed preparation of drug, dosage and mode of use is given under uses. 


\section{Abrus precatorius Linn.}

Syn.: A. minor Desv. A. pauciflorus Desv.

Family: Fabaceae.

Tel.: Ghurie-ghenza.

Description: Perennial twiner. Leaves paripinnate leaflets opposite, oblong, blunt. Flowers pink or white in racemes. Pods flat, beaked, and silky. Seeds scarlet.

with a black spot, polished, shining.

Flowering: Sept.-Oct. Fruiting: Oct.-Nov.

Folk Uses:-Leaves are eaten with sugar cube to cure mouth ulcer.

2. Abutilon indicum (Linn.) Sw.

Syn: Sida india Linn.

Family: Malvaceae.

Tel.: Adavibenda.

Description: A small shrub, hairy. Leaves cordate, ovate, acuminate, toothed, and stipulate. Flowers yellow. Seeds brown.

Flowering: Oct.-May. Fruiting: Nov.-June.

Folk Uses: - Leaves ground with butter milk and extract given orally for thrice a day to cure dysentery.

3. Acacia leucophloea (Roxb.) Willd.

Syn.: A. alba Willd, A. arcuata, Decaisne Herb. Mimosa alba Rottl., $M$.

Leucophloea Roxb.

Family: Mimosaceae.

Tel.: Tella-tuma.

Description: A medium-sized, deciduous tree with yellowish bark. Leaves bipinnate, leaf lets 12-30 pairs.

Flowers in terminal, head creamy to pale yellow. Pods flats, linear-oblong. Seeds spherical, pale-brown.

Flowering: Sept.-Nov. Fruiting: Nov.-Mar.

Folk Uses: $20 \mathrm{~g}$ root paste is given on empty stomach as an abortifacient.

4. Acacia nilotica (Linn.) Del. Subsp. indica (Benth) Bren.

Syn.: A. arabica Willd.

Family: Mimosaceae.

Tel.: Nalla tumma.

Description: A moderate-sized ever green tree. Leaves bipinnately compound. Flowers golden yellow in globose heads. Fruits stalked compressed. Seeds 8-12, black-brown, smooth.

Flowering: May-Oct. Fruiting: June-Nov.

Folk Uses: Young pod piece is kept in the mouth to hasten healing mouth ulcer.

5. Achyranthes aspera Linn.

Syn: A. wightiana Wall. A. lanceolata Wall.

Family: Amaranthaceae.

Tel: Antisha, Utta-revi.

Description: An annual, erect herb, $90-180 \mathrm{~cm}$ tall with leathery leaves abruptly attenuated at the base. Branches some what 4-sides. Flowers grayish white, borne in terminal, robust spikes, 30-40 sum long and sharply deflexed against its rachis. Seeds inverted.

Flowering: Sept.-Dec. Fruiting: Sept.-Jan.

Folk Uses: - Juice extracted from whole plant paste is given 1 teaspoon full 3 times a day for 3 days to patients of Asthma.

6. Adhatoda zeylanica Medic.

Syn.: Justicia adhatoda Linn. Adhatoda vasica Nees.

Family: Acanthaceae.

Tel: Adasara, Addasaram

Description : Tall, strong-smelling, glabrous shrubs with 2-lipped, irregular, white streaked pink dotted flowers in short spikes having overlapping bracts, capsule hairy 4 -seeded. Seeds glabrous.

Flowering: Dec.-Feb. Fruiting: Dec.-Feb.

Folk Uses: - 2-3 drops leaf extract is given orally to children in cough.

7. Aegle marmelos (Linn.) Corr.

Syn.: Crataeva marmelos Linn. C. religiosa Ainslie, Feronia pellucida Roth.

Family: Rutaceae. 
Tel.: Bilvabandu, Maluramu, Maredu, Patir.

Distribution: India, Sri Lanka.

Description: A small thorny tree. Leaves trifoliate, aromatic; leaflets lanceolate. Flowers greenish white scented. Fruits globose. Seed numerous oblong.

Flowering: Mar.-Apr. Fruiting: Apr.-June.

Folk Uses: - The tree is sacred to the tribals. One spoon of stem bark is taken orally with half glass of water daily once to cure piles.

8. Balanities aegyptiaca (Linn.) Del.

Syn: B. roxburghii Planch. Ximenia aegyptiaca Roxb. Ximenia aegyptiaca

Roxb.

Family: Balanitaceae

Tel.: Garachettu, Gara-pandu, Gari, Ringri.

Description: A small, not very spreading tree or shrub, stem woody cylindrical. Leaves alternate. 2-foliolate compound. Flowers pale greenish yellow, fragrant, in axillary few flowered cymes or fascicles. Drupe ovoid yellowish green when ripe. Seed solitary pendulous.

Flowering: Mar.-Apr. Fruiting: Apr.-Feb.

Folk Uses: - 5-10 g powder of fruit Pericarp mixed with sugar cube is given orally twice a day for 3-4 days to cure cough.

\section{Barleria prionitis Linn.}

Family: Acanthaceae.

Tel.: Ettapulapeddagoranta.

Description: Erect hairy herb up to $120 \mathrm{~cm}$ tall with lilac. Flowers crowded in short, nearly sessile axillary spikes and conspicuous bracteoles. Seeds compressed, silky hairy.

Flowering: Sept.-Jan. Fruiting: Sept.-Jan.

Folk Uses: - Whole plant burnt and made into powder. Half spoon of powder mixed with honey is taken orally for cough.

\section{Bauhina racemosa Lam.}

Family: Caesalpiniaceae.

Tel: Devakanchana

Description: A deciduous tree with deeply cordate leaves and large, fragrant

flowers. Pods hard, flat, 12-15 seeded.

Flowering: Nov.-Jan. Fruiting: Dec.-Feb.

Folk Uses: - Stem is used for making 'Ada', 'Dhosari'. A pinch of dried powdered flowers with honey recommended for diarrhoea and vomiting.

11. Calotropis procera (Ait.) Ait. f.

subsp.hamiltonii (w) Ali.

Syn: C. hamiltoni Wall. C. wallichii Wight. C. heterophylla Wall.

Family: Asclepiadaceae

Tel.: Mandaram.

Description: A small shrub. Leaves decussate, smaller, ovate-oblong, elliptic or obovate, abruptly acuminate, cottony-hairy when young only. Flowers pale purplis smaller, buds hemispherical not angled, in umbellate cymes. Strongly scented. Fruit a pair of follicies.

Flowering: All months. Fruiting: All months.

Folk Uses:- Leaves crushed with stem barks of Strychnos nux-vomica, Cassia auriculata and small quantities of roots of Rauvolfia serpentina and Tinospora cordifolia are made into soap nut seed sized tablets. One tablet is administered twice a day till cure for snake bite.

12. Cassia auriculata Linn.

Syn: Senna auriculata Roxb.

Family: Caesalpiniaceae.

Tel.: Tangedu, Thagedu-tangar.

Description: A much branched shrub. Leaves paripinnate, leaflets 8-12 pairs elliptic, oblong, obtuse, and minutely apiculate, with subulate glands in between. Flowers large, showy, yellow in axillary corymbose racemes. Pod flat, thin papery, oblong, obtuse, depressed between the seeds.

Flowering: All months. Fruiting: All months.

Folk Uses:- One to two spoons of shade dried plant powder is administered daily once to cure diabetes. 


\section{Cassia fistula Linn.}

Syn: C. rhombifolia Roxb.

Family: Caesalpiniaceae.

Tel.: Rela-kayalu, Relarala,

Reylu, Suvarnam.

Description: A small to medium-sized tree. Leaves paripinnete, stipules small, leaflets 4-8 pairs, large ovate, acute, base wedge-shaped-flowers in drooping racemes, yellow, fragrant. Pods long, cylindric, pendulous indehiscent. Seeds ovate, many, imbedded horizontally in sweet, dark-coloured pulp.

Flowering: Apr.-May. Fruiting: May-June.

Folk Uses: - One spoon of fruit pulp is administered with sugarcane juice to cure jaundice.

\section{Cleome gynandra Linn.}

Syn: Gynandropsis pentaphylla DC. G. gynandra (Linn.) Briquet.

Family: Capparidaceae.

Description: An annual, erect, branched, hairy herb. Leaves 3-5 foliate, petioles long, leaflets sub-sessile, elliptic, obovate, acute, and hairy on both sides. Flowers white or pale pink, at first corymbose, elongating into a raceme with bracts which are trifoliate. Fruit a long siliqua. Seeds rough.

Flowering: Aug.-Oct. Fruiting: Sept.-Nov.

Folk Uses:- Vapour of boiling seeds is inhaled thrice a day to cure cough.

15. Cleome viscosa Linn.

Syn: C. icosandra Linn., Polanisia viscose (Linn.) Dc., P. icosandra Wt. \&

Arn.

Family: Caparidaceae.

Tel. : Kukka vaminta.

Description: An erect, glandular-pubescent, annual herb. Stem angular, grooved, hairy. Leaves large but upper leaves small, leaflets elliptic-oblong, acute, the terminal largest. Flowers yellow, axillary growing into loose raceme. Fruit a long siliqua, hairy, ending in a style. Seeds many, black, and subglobose.

Flowering: Aug.-Sept. Fruiting: Sept.-Oct.

Folk Uses:- Leaves paste is applied externally to cure wounds in cattle. Leaves used as a vegetable. It is good in taste and is used as a diuretic.

16. Lannea coromandelica (Houtt.) Merr.

Syn: Odina woodier Roxb. Dialium coromandelicum Houtt., Lannea grandis

Engler.

Family: Anacardiaceae.

Tel.: Uddimanu.

Description: A small to moderate sized deciduous tree, trunk thick, bark exfoliating, young parts hairy. Leaves with 3-5 pairs of leaflets and an odd one, membranous, green above and brown below, ovate-oblong, acute, tinged with pink when young, base oblique. Flowers unisexual, yellowish-green, male and female on different branches, male racemes compound, female simple. Drupe reniform, compressed, red.

Flowering: Feb.-Mar. Fruiting: Mar.-Apr.

Folk Uses:- If snakebite produces swelling, then bark of stem is made into paste with cow urine and applied over swelling. The cow urine is sprinkled on to keep it wet. This acts as an anti-inflammatory agent.

17. Lantana camara Linn.

Syn: L. aculeata Linn.

Family: Verbenaceae.

Tel.: Pulikampa.

Description: A hairy, spiny, rambling, evergreen shrub with tetragonous branches and flowers in long-stalked heads. Drupe black, shining.

Flowering: All months. Fruiting: All months.

Folk Uses: - Chewing and massaging flower over gums is helpful in bleeding gums and decaying teeth.

18. Luffa acutangula Var. amara Clarke

Syn: L. amara Roxb.

Family: Cucurbitaceae.

Tel.: Birakya, Verribeera.

Description: A large monoecious climber, stems 5-angled, tendrils usually 3- fid. Leaves orbicular, palmately 5-7-angled, scabrid on both sides, base cordate. Male flowers in axillary 12-20 flowered racemes, yellow with green hairy veins, female flowers solitary. Pepo small 10-ribbed, seeds black, ovoid. 
Flowering: Aug.-Sept. Fruiting: Aug.-Sept.

Folk Uses:- $500 \mathrm{~g}$ fresh whole plant material is boiled in $250 \mathrm{ml}$ water, concentrated and taken while warm to get relief from insect bite.

19. Martynia annua Linn.

Syn: $M$. diandra Linn.

Family: Martyniaceae.

Tel.: Garudamukku.

Description: An erect, widely branched, glandular hairy herbs, stem thick, subterete, fistular. Leaves broadly ovate-orbicular, cordate at base, sub obtuse at apex. Inflorescence in axillary racemes, flowers pale pink or purple. Capsule 1 seeded long horned.

Flowering: Aug.-Dec. Fruiting: Aug.-Dec.

Folk Uses:- Fruits are pounded with water and the paste is applied on the bitten areas for scorpion sting.

20. Maytenus emarginata (Willd.) Ding.

Syn: M. senegalensis (Lam.) Exell., Gumnosporia montana (Roth) Benth., celastrus senegalensis Lam.

Family: Celastraceae.

Tel.: Danti, Pedda chintu..

Description: A small compact tree. Young branches purple, often spine, with leaves and flowers on the spines. Leaves coriaceus, much variable in size and shape elliptic or obovate. Flowers prolific in di or tri-chotomous, axillary cymes or fascicles, white. Fruits puple or nearly black when ripe, coriaceous. Seeds 1-2, rarely 3.

Flowering: Oct.-Dec. Fruiting: Nov.-Jan.

Folk Uses:- The fresh root bark is ground into paste and mixed with water. One teaspoon of the decoction is taken daily for 5 days to expel worm from the human body. 10 to 15 Leaves with sugar cube taken orally two times for 7 days to cure jaundice.

21. Nymphaea pubescens Willd.

Syn: N. Stellata Willd., N. sagittata Edgeworth.

Family: Nymphaeceae.

Description: Aquatic rhizomatous herbs. Leaves oblong or rotundate, hastate, entire or sinuate margined, uillous beneath, petioles and peduncles smooth, purplish. Flower purple white. Fruit a fleshy berry globose and green surrounded by the persistent, green filaments of the stamens forming a corona on the top. Seeds many.

Flowering: Aug.-Oct. Fruiting: Sept.-Nov.

Folk Uses: - Half cup of fruit juice is mixed with little amount of sugar and administered daily thrice to cure menorrhagea.

22. Ocimum basilicum Linn.

Syn: O. pilosum Willd. O. album Linn. O. minimum Burm. O. hispidum

Lamk. O. methaefolium Benth.

Tel. Rudrajada, Vipudi-patri.

Family: Lamiaceae

Description: An erect softly hairy strongly scented annual with small pinkish white flowers in densely racemose whorls. Nutlets ellipsoid, pitted.

Flowering: July-Oct. Fruiting: July-Dec.

Folk Uses:- 3-4 drops of leaves exstract are pored in ear to cure earache.

23. Ocimum canum Sims

Syn: O. americanum Linn.

Family: Lamiaceae

Tel : Kukka tulsi,

Description: A small, annual herb much branched hairy. Leaves elliptic. lanceolate, acute at, both ends, entire, gland-dotted. Inflorescence terminal racemes; flower white or pink. Fruit carcaerulus splitting in to 4 nutlets

Flowering: July-Dec. Fruiting: July- Dec.

Folk Uses: One to two drops of leaf juice is instilled into the affected ears to cure earache.

24. Ocimum sanctum Linn.

Syn: O. inodorum Burm. O. monachorum Linn. O. tenuiflorum Linn.

Family: Lamiaceae.

Tel.: Graggera-chettu, Krushna-tulasi, Tulasi. 
Description: An annual, much branched herb, stem square, hairy, purplish. Leaves opposite decussate, ellipticoblong, obtuse or acute, entire or serrate, hairy, minutely gland dotted. Flowers purplish in racemes formed of many verticillasters. Nutlets 4 surrounded by persistent Calyx.

Flowering: Sept.-mar. Fruiting: Sept.-Mar.

Folk Uses: - Leaves used for flavoring tea. Decotion of leaves taken orally to cure cold and cough.

25. Phoenix sylvestris Roxb.

Syn: Elate sylvestris Linn.

Family: Arecaceae.

Tel.: Ita, Peddayita.

Description: palm trunk stout, clothed with persistent leafbaes. Spadices erect. Fruits scattered on long, pendulous spikes.

Flowering: Jan.-Mar. Fruiting: Jan.-June.

Folk Uses:- Leaf and tuber are ground together and the paste is massaged under the foot for burnings sensation.

26. Phyllanthus fraternus Webster.

Syn: $P$. asperulatus Sensu, $P$. niruri auct. non. Linn.

Family: Euphorbiaceae.

Tel: Nelausirika;

Description: $20-50 \mathrm{~cm}$ annual, erect herbs. Leaves alternate. Inflorescence axillary; flower pale-greenish-

yellow. Fruit capsule; seed tri-gonous.

Flowering: All months. Fruiting: All months.

Folk Uses: Plant extract is given orally once or twice in a day to cure fever in children.

27. Plumbago zeylanica Linn.

Syn: $P$. auriculata Blume, Thela alba Lour.

Family: Plumbaginaceae.

Tel: Agnimata, Chitra-mulam;

Description: A rambling subscandent perennial herb. Stem clasping. Flowers white, in long spikes; rachis glandular. Capsule included.

Flowering: Sept.-Nov. Fruiting: Sept.-Nov.

Folk Uses: Drink powder of root, bitter leaves of Azadirachta indica, leaves of piper longum leaves of Terminalia chebula and table salt with boiled water to cure fever.

28. Pterocarpus marsupium Var. acuminatus Prain.

Family: Fabaceae.

Tel.: Beddagi, Asana.

Description: A tall deciduous tree. Leaves large. 15-30 cm long with 5-7 leathery alternate leaflets, sometimes notched at the tip or round, stalk of leaflets. Flowers fragrant yellow in paniculate racemes. Pods light yellowish brown with woody centre and waved membranous wing, usually one seeded. Seed reddish brown small and leathery.

Flowering: May-June. Fruiting: June-July.

Folk Uses: - Fifty g of stem bark is crushed and boiled in 2 glasses of water till it gets reduced to half glass. It is taken orally twice a day to cure leucoderma.

\section{Punica granatum Linn.}

Syn: P. nana Linn.

Family: Punicaceae.

Tel.: Dadimanu, Dadimba

Description: Deciduous shrub with axillary thorns. Flowers scarlet, solitary axillary. Fruits globular, crowned with persistent calyx.

Flowering: Apr.-July. Fruiting: Apr.-July.

Folk Uses: - 1 glass juice of fruits is taken orally three times a day for a week to cure diarrhoea. Fruit is edible.

30. Sida cordifolia Linn.

Syn: S. herbacia Micans, S. althaeifolia Sw., S. rotundifolia Cav.

Family: Malvaceae.

Tel.: Antisa, Chirbendel.

Description: A small, softly hairy, much-branched, annual erect herb with linear stipules. Leaves cordate, obtuse, crenate, peioles long. Flowers paleyellow, solitary or few together. Fruit reticulated, seeds black.

Flowering: Sept.-Oct. Fruiting: Oct.-Nov. 
Folk Uses:- 2 teaspoonful decoction of roots given orally twice a day for 5 days for urinary troubles.

\section{Solanum surattense Burm.}

Syn: S. armatum Br., S. jacquinii Willd. S. diffusum Roxb., S. virginianum

Jacq. S. xanthocarpum Schrad \& Wendl., S. maccanni Sant.

Family: Solanaceae.

Tel.: Nelamulaka, Pinnamulaka, Vankuda.

Description: A prickly, procumbent perennial with many straight spines on leaves. Flowers blue, in fewflowered extra-axillary cymes. Berries globose, yellow when ripe.

Flowering: Sept.-May. Fruiting: Sept.-May.

Folk Uses:- Powdered fruits are boiled in mustard oil and cooked. This medicated oil is applied on skin eruptions on foot during winter.

\section{Soymida febrifuga A. Juss.}

Family: Meliaceae.

Tel.: Sonida manu.

Description: A large, tall tree, leaflets 3-6 pairs, oval or oblong, obtuse, oblique. Flowers greenish white. Capsule obovoid, black, seeds winged.

Flowering: Feb.-Mar. Fruiting: Mar.-Apr.

Folk Uses:- $1 / 2$ cup decoction of stem bark is given orally in snake bite.

\section{Sterculia urens Roxb.}

Family: Sterculiaceae.

Tel.: Kalvi.

Description: A moderate sized tree with an irregular, gnagled short trunk. Leaves at ends of branches, palmately 5-lobed pointed at the tip heart shaped. Flowers yellow, glandular-hairy, in bunches at the end of the branches when the tree is leaflets, male and female or bisexual flowers mixed. Fruit an etaerio of 4-5 folicles, ovoid-oblong hairy, brown in colour. Seeds 3-6, oblong black.

Flowering: Mar.-Apr. Fruiting: Apr.-May.

Folk Uses: - Stem bark with that of Madhuca longifolia is made into powder. One to two spoons of it is taken with one cup of water for easy delivery.

\section{Terminalia chebula Retz.}

Syn: T. aruta Ham. T. reticulata Roth. Embryogonia arborea Teys.And

Binn., Myrobalanus chebula Gaertn.

Family: Combretaceae.

Tel.: Kadukar, Karaka, Karaku,

Karakkaya (ripe fruit), Kurka.

Description: A small tree. Leaves alternate, elliptic oblong, acute, penninerved, base rounded, petioles often with 2 glands near their apex. Flwers in terminal spike, braceoles exceeding the flowers linear, acute. Drupes ellipsoid or obovoid stone oblong bony. Seed exalbuminous.

Flowering: Apr.-May. Fruiting: May-June.

Folk Uses: - 15-20g stem bark paste is taken in slightly hot water once a day for 3 days to cure gastric troubles.

35. Thespesia populnea Corr.

Syn : Hibiscus populneoides Roxb., H. populneus Linn., Malvaviscua populneus Gaerth.

Family: Malvaceae.

Tel.: Gangaravi, Gangaraya, Gangarenu, Gangirana, Muniganga-ravi.

Description: A small evergreen tree with an umbrella shaped crown. Leaves poplar-like, heart shaped, entire ponted at the tip, petiole $2.5-10 \mathrm{~cm}$, stipulg awl-shaped, deciduous. Flowers axillary, solitary or two together, bisexual, bell-shaped, yellow. Fruit a globose capsule covered with minute stalked scales, calyx persistent black when ribe. Seeds ovoid.

Flowering: All months. Fruiting: All months.

Folk Uses: - Extract of 3-4 fleshy leaves ground with an equal quantity of cow milk. This mixture is taken on empty stomach early in the morning for seven days, it is effective remedy for jaundice.

36. Thevetia peruviana (Pers.) Merr.

Syn: T. nerifolia Juss ex Steud.

Family: Apocynaceae.

Tel.: Pachaganneru. 
Description: A small tree with milky juice. Leaves numerous, alternate, close together, linear, acute. Flowers yellow, fragrant, in axillary or terminal cymes. Fruit a fleshy drupe, 4-angled, compressed with a ridge, seed 2 to 4.

Flowering: All months. Fruiting: All months.

Folk Uses:- Flowers are collected in the early morning. The smell of the flower is inhaled seven times to cure a boil in the nostrils.

37. Vernonia cinerea (Linn.) Less.

Syn: Conyza cinerea Linn.

Family: Asteraceae.

Tel.: Gharitikamini, Garitikamma.

Description: A small annual herb, stem hairy. Leaves simple, alternate, ovate elliptic or lanceolate, obtuse or acute, mucronate, irregularly dentate or crenate serrate, hairy. Flowers pinkish-violet, in small heads forming divaricated terminal corymbs. Cypsela square, oblong, narrow at base, hairy.

Flowering: Aug.-Mar. Fruiting: Aug.-Mar.

Folk Uses: - Leaf juice is applied on cuts and wounds to check bleeding and as an antiseptic also. Decoction of whole plant is given in the morning in empty stomach to cure fever.

38. Vitex negundo Linn.

Syn: V. bicolor Wild. V. arborea Desf., V. Paniculata Lamk.

Family: Verbenaceae.

Tel.: Nallavavili, Vavili.

Description: A deciduous shrub with digitately compound leaves and bluish purple flowers in pedunculate branched cymes. Fruits drupaceous, black when ripe.

Flowering: All months. Fruiting: All months.

Folk Uses: - Water boiled with leaves is used for bath (7-8 days) in scabies. Smoke of leaves is used as a Insect repellent.

39. Wattakaka voluble (Linn.f.) Stapf.

Syn: Dregea Volubilis (Linn.f.) Bth. ex. Hk., Asclepias volubilis Linn.f.

Marsdenia volubilis Cooke.

Family: Asclepiadaceae.

Description: A stout woody pubescent twiner. Leaves broadly ovate to sub orbicular, cordate. Flowers green, in dense. Drooping umbels. Follicles paired, divaricated, tapering from base. Seeds ovoid, glabrous.

Flowering: Aug.-Sept. Fruiting: Sept.-Oct.

Folk Uses:- Fresh tender branch is taken and 2-3 drops latex is poured in nose to cause sneezing to cure headache.

40. Woodfordia fruticosa Kurz.

Syn: W. floribunda Salisb. W. tomentosa Bedd. Grislea tomentosa Roxb. G.

punctata Ham., Lythrum fruticosum Linn.

Family: Lythraceae.

Tel.: Gaji-godari, Kusumamu.

Description: A small much-branched shrub. Flowers red, in short panicle cymes. Capsule included.

Flowering: Mar.-Apr. Fruiting: Apr.-May.

Folk Uses:- 1 teaspoonful in fusion of flower is given 2 times a day in dysentery.

41. Wrightia tinctoria $\mathrm{Br}$.

Syn: Nerium tinctorium Roxb.

Family: Apocynaceae.

Tel.: Amkudu,

Description: A deciduous tree of moderate size, with an irregularly-shaped trunk. Leaves opposite, variable, elliptic-lanceolate, shortly acuminate. Flowers white or pale yellow, scented in terminal cymes, bracts small. Fruit a pair of follicles, drooping, united at the tips only in the earlier stages.

Flowering: Mar.-Aug. Fruiting: Apr.-Sept.

Folk Uses:- $10 \mathrm{ml}$ of stem bark juice is taken internally two times a day for 3 days against dysentery.

42. Xathium strumarium Linn.

Syn: $X$. indicum Dc, $X$. roxburghii Discolor, X. orientale Blume.

Family: Asteraceae.

Tel.: Marulamatangi, Parsvapu. 
Description: A coarse annual, unarmed herb with 3-lobed leaves and greenish white heads in terminal and axillary racemes. Achenes clothed with strong hooked spines.

Flowering: Aug.-Jan. Fruiting: Aug.-Jan.

Folk Uses: - 3-4 drope of leaves extract is pored in ear to cure earache.

43. Zingiber officinale Rosc.

Family: Zingiberaceae.

Tel.: Allamu.

Description: A small herb with horizontal, fleshy rhizomes. Leaves distichous linear, lanceolate. Flowers in long spikes, bracts, one-flowered, purple.

Flowering: Mar.-Apr. Fruiting: -

Folk Uses:- About $15 \mathrm{~g}$ of the rhizome is cooked with $20-25 \mathrm{~g}$ jaggery and given against cough.

\section{RESULT AND DISCUSSION}

Ethno floristic exploration was made during the period 2011-2012 covering all the villages of Vizianagaram District, All tribal Mandalam. The total number of species is segregated according to the family. Thus the family-wise analysis of the ethnic species revealed that, 43 species belonging to 36 families. Among them, Malvaceae, Caesalpiniaceae and Lamiaceae is in hierarchy with 3 species followed by Fabaceae, Mimosaceae, Acanthaceae, Asclepiadaceae, Capparidaceae, Verbenaceae, Apocynaceae and Asteraceae with 2. The drug yielding plants are statistically analysed based on their morphological habit and revealed that herbs dominated with 17 species followed by trees 14, shrubs 9 and climbers 3 (Fig. 1).

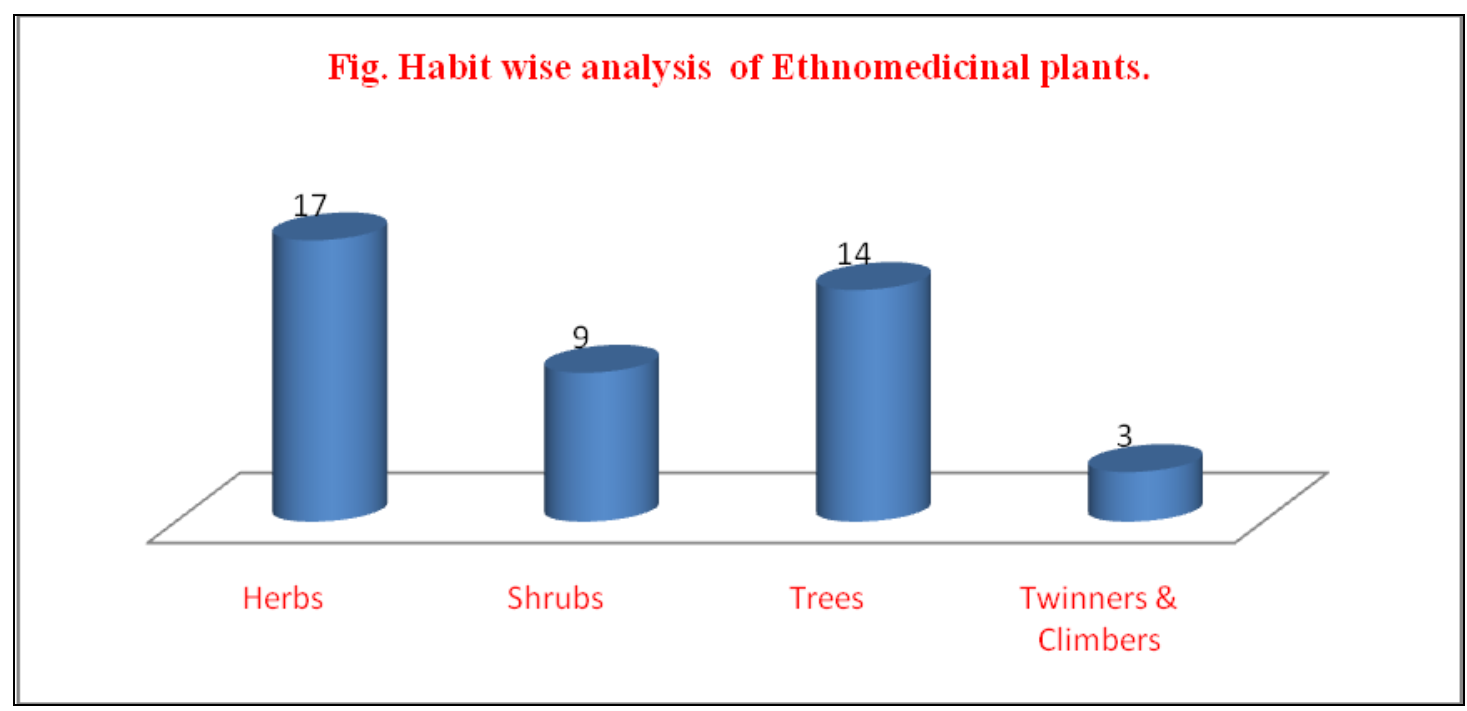

Different parts or products of medicinal plants are employed for ethnomedicinal purposes like root, root bark, tuber, stem, stem bark, tender branch, rhizome, leaf, flower, fruit, seed, whole plant and latex, gum in different formulations like decoctions, infusion, extract, paste, powder, etc. are in practice. It is probably that the whole herb/plant is thought worth more by the tribal medicine men than the sum total of its parts. Based on the study the different plant parts that are used in crude drug preparation to cure 25 types of diseases. More prevalent diseases are Dysentery, Mouth ulcers, Abortifacient, Asthma, Cough, Piles, Diarrhoea, Vomiting, Snake bite, Diabetes, Jaundice, Wounds, Diuretic, Scorpion sting, Menorrhea, Earache, Burning sensation, Leucoderma, Skin troubles, Boils, Fever, Insect repellent, Headache etc.,

Most of the time the drug is utilized in the fresh or dried state, the most frequently used traditional medicine preparations are powders, concentrated extracts or pastes, juices, decoction and oil or fats. The medicines are given orally or by external applications. The methods and period of administration may be widely different. The dosage and duration of intake of these crude drugs may slightly vary from one healer to another. Most popular method of application of plant material is the direct application. It may be either fresh or in dried form. Fresh materials are usually taken orally or applied externally. Dried materials are powdered and taken along with milk or water. It can be kept for future use also. Another most common practice is the medicated oils especially for skin diseases. It is prepared by boiling the crushed or minced plant materials in oil until it loses entire water content. Application of liquid preparations (decoctions) is also common. Decoctions are prepared by boiling the powdered, crushed or minced plant material with water and removing the residue by filtration. 


\section{CONCLUSION}

The medico-botanical survey of the area revealed that the people of the area possessing good knowledge of herbal drugs but as the people are in progressive exposure to modernization, their knowledge traditional uses of plants may be lost in due course. So it is important to study and record the uses of plants by different tribes and sub-tribes for futures study. Such studies may also provide some information to biochemists and pharmacologists in screening of individual species and in rapid assessing of phyto-constituents for the treatment of various diseases.

\section{ACKNOWLEDGEMENT}

The authors are very much thankful to the Tribal people of Vizianagaram district for sharing their valuable knowledge and help during field work.

\section{REFERENCE}

[1]. Jain, S. K. Wild plants foods of the tribals of Bastar (Madhya Pradesh). Proc. Nat. Inst. Sci. India, 1964. 30B: 56-60.

[2]. Jain, S. K., (Ed.). Glimpses of Indian ethnobotany. Oxford and IBH Publishing Co., 1981. New Delhi.

[3]. Jain, S. K., (Ed.) 1981. Glimpses of Indian ethnobotany. Oxford and IBH Publishing Co., New Delhi.

[4]. Chadwick, D. J. and J. Marsh (ed.). Ethnobotany and the search for new Drugs. 1994. John Wiley \& Sons, Chichester, U.K

[5]. Hemadri, K., and S. S. Rao. Jaundice. Tribal medicine. Ancient Sci. Life, 1984. 3: 209-212.

[6]. Martin, G. Ethnobotany - A method manual. Chapman \& Hall, 1995. London.

[7]. Gamlbe, J. S. and C. E. C. Fischer. Flora of Presidency of Madras, (3 vols.) (repr. Ed. 1957) Botanical Survey of India, 19151935. Howrah.

[8]. Pullaiah, T., and E. Chennaiah. Flora of Andhra Pradesh (India). Department of Botany, Sri Krishnadevaraya University, Anantapur, India. Scientific Publishers, 1997. Jodhpur, India.

[9]. Aminuddin and R D. Girach. Ethnobotanical studies on bondo tribe of district Koraput (Orissa). India. Ethnobotany, 1991. 3: 15-19.

[10]. Balaji Rao, N. S., D. Rajasekhar, D. Chengal R'ajuand N. Nagaraju. Folk medicine of Rayalaseema Region, Andhra Pradesh: 1 Dental protector. Ancient Sci. Life, 1995. 15: 15 - 20.

[11]. Basi Reddy, M., K. Raja Reddy and M. N. Reddy. A survey of medicinal plants of Chenchu tribes of Andhra Pradesh, India. Int. Jour. Crude Drug Res, 1988. 26: 189-196.

[12]. Chandra, V. Medicinal plants used by the tribals of Arunachal Pradesh. A Preliminary Study. J. Econ. Tax. Bot, 1989. 13: 391394.

[13]. Girach, R. D. Medicinal plants used by Kondh tribe of district Phulbani (Orissa)in Eastern India. Ethnobotany, 1992. 4: $53-66$.

[14]. Girach R. D., Aminuddin and P. A. Siddique. Traditional plant remedies among the Kondh of District Dhenkanal (Orissa). Int. J. Pharmacog, 1994. 32: 274-283.

[15]. Gupta, A. K., Mishra, S. K. and A. A. Khan. Ethnobotanical notes on some herbs from Chhattisgarh region of Madhya Pradesh. Advances in plant Scinces, 1999b. 12: 163-166.

[16]. Hemadri, K. Tribals of Andhra Pradesh and 'their knowledge in nutritional and medicinal herbs. Indian Medicine, 1992. 3: 1734.

[17]. Islam, M. Ethnobotatany of bark of Certain Plants of North-East India. J.Econ. Taxon. Bot, 2000. 24 : 419 - 432.

[18]. Krishna Prasad, V., T. Rajagopal, Yogeshkant and K. V. S. Badarinath. Food plants of Konda Reddies of Rampa Agency, East Godavari district, Andhra Pradesh. A case study. Ethnobotany, 1999. 11: 92-96.

[19]. T. Dharamachandra Kumar. Herbal plants in Mannanur forest, Mahaboobnagar district, Andhra Pradesh. J. Econ. Tax, Bot, 1996. 12: $218-220$.

[20]. Raju V.S. \& K. N. Reddy. Ethnobotanic medicine for Dysentery and Diarrhoea from Khammam District of Andhra Pradesh, India. Indian Journal of Traditional Knowledge, 2005. Vol. 4(4), pp. 443-447.

[21]. Reddy, R V., M. Hemambara Reddy and R R Yenkata Raju. Ethnobotanyof less known tuber-yielding plants from Andhra Pradesh, India. Jour. Nontimber forest products, 1996. 3(112): 60-63.

[22]. Venkaiah, M. Ethnobotany of some plants from Vizianagaram District, Andhra Pradesh. Flora and Fauna, 1998. 4: 90-92.

[23]. Yoganarasirnhan, S. N. and P. K. Dutta. Medicinal plants of Orissa in and around Bhubaneswar. Nagarjun, 1970. 14: 15-20.

[24]. Yogendra Kumar, Fancy Scarlet and R. R. Rao. Contributions to the ethnobotany of Meghalaya Plants used by "War Jaintia" of Jaintia Hills District. J. Econ. Tax. Bot., 1987. 11(1): 67-70. 